\title{
Fast water currents reduce production performance of post-smolt Atlantic salmon Salmo salar
}

\author{
Frida Solstorm ${ }^{1,2, *}$, David Solstorm ${ }^{1}$, Frode Oppedal $^{1}$, Anders Fernö ${ }^{2}$, \\ Thomas William Kenneth Fraser ${ }^{3}$, Rolf-Erik Olsen ${ }^{1}$
}

\author{
${ }^{1}$ Institute of Marine Research, 5984 Matredal, Norway \\ ${ }^{2}$ Department of Biology, University of Bergen, PO Box 7803, 5006 Bergen, Norway \\ ${ }^{3}$ Norwegian School of Veterinary Science, 0033 Oslo, Norway
}

\begin{abstract}
In the future, an increasing number of salmon farms may be located in areas with fast water current velocity due to limited availability of more sheltered locations. However, there is little information as to how fast currents affect fish health and welfare. We used raceways to expose Atlantic salmon post-smolts $(98.6 \mathrm{~g}, 22.3 \mathrm{~cm})$ to homogeneous water velocities corresponding to $0.2,0.8$ and 1.5 body lengths $\mathrm{s}^{-1}$ (slow, moderate and fast, respectively) over $6 \mathrm{wk}$. Fish at fast velocity had a $5 \%$ lower weight gain compared to fish at moderate and slow velocities, with a corresponding reduction in length. Fish at moderate and fast velocities had lower lipid content in the muscle compared to fish at slow velocity. Hence, fish at slow and moderate velocities had the same weight gain, but fish at slow velocity gained more fat and fish at moderate velocity more muscle protein. Fish at fast velocity had a higher relative ventricular mass, indicating an increased cardiac workload. At slow velocity, individual fish displayed elevated plasma levels of lactate, osmolality and potassium. Our results suggest that post-smolts had the best growth and welfare at moderate velocity and that a current velocity of 1.5 body lengths $\mathrm{s}^{-1}$ could compromise production performance.
\end{abstract}

KEY WORDS: Aquaculture $\cdot$ Welfare $\cdot$ Exercise $\cdot$ Growth $\cdot$ Swimming $\cdot$ Stress

\section{INTRODUCTION}

Traditionally, fish farms have been located in sheltered areas. However, environmental aspects and conflicting interests regarding usage of coastal waters in populated areas have contributed to an increased number of farms being located in exposed areas (Stickney \& McVey 2002, Benetti et al. 2010, Holmer 2010). Areas with fast current velocity may improve water quality by increased water exchange in cages, and the technology for constructing cages capable of withstanding such external forces is well developed (Fredheim \& Langan 2009). However, there is a lack of knowledge when it comes to how fast water currents affect the performance and welfare of caged fish.

\footnotetext{
${ }^{*}$ Corresponding author: frida.solstorm@imr.no
}

In areas with slow currents, fish have the option to vary their swimming speed. In exposed areas with faster currents, fish are forced to swim at the prevailing velocity to maintain their position (Johansson et al. 2014). When the current is not restricting the fish, they may be able to choose their preferred swimming speeds. For adult brook charr Salvelinus fontinalis, preferred swimming speeds lie between 0.78 and 0.95 body lengths (BL) s ${ }^{-1}$ (Tudorache et al. 2011). In adult Atlantic salmon Salmo salar, daytime swimming speed in cages appears to vary between studies, ranging from 0.4 to $1.5 \mathrm{BL} \mathrm{s}^{-1}$ (Sutterlin et al. 1979, Kadri et al. 1991, Blyth et al. 1993, Andrew et al. 2002, Dempster et al. 2008, Korsoen et al. 2009). However, the swimming speeds measured in sea cages are rarely corrected for ambient current veloc-

() The authors 2015. Open Access under Creative Commons by Attribution Licence. Use, distribution and reproduction are unrestricted. Authors and original publication must be credited. 
ity, which could explain the variation in observed swimming speeds.

Swimming as a form of exercise is often perceived as positive for fish welfare. For example, increased growth and protein deposition following exercise have been reported in several salmonid species at water velocities ranging from 0.80 to $1.75 \mathrm{BL} \mathrm{s}^{-1}$ (East \& Magnan 1987, Houlihan \& Laurent 1987, Totland et al. 1987, Christiansen \& Jobling 1990, Jørgensen \& Jobling 1993, Davison 1997, Castro et al. 2011). For juvenile Atlantic salmon, Jørgensen \& Jobling (1993) showed a maximal specific growth rate when fish were exercised at $1.5 \mathrm{BL} \mathrm{s}^{-1}$ compared to 0,1 and $2 \mathrm{BL} \mathrm{s}^{-1}$. For pre-smolts, Castro et al. (2011) reported a $20 \%$ increase in growth when salmon were exercised continuously or at intervals $\left(0.8-1.0 \mathrm{BL} \mathrm{s}^{-1}\right)$ compared to controls $\left(0.05 \mathrm{BL} \mathrm{s}^{-1}\right)$. Reduced ATP depletion after fatigue challenge and increased energy stores in muscle occurs in rainbow trout Oncorhynchus mykiss as an effect of exercise (Pearson et al. 1990, McFarlane \& McDonald 2002). Other positive effects of exercise include increased cardiac output (Farrell et al. 1991), ventricular mass (Gallaugher et al. 2001, Castro et al. 2013), intestinal blood flow (Thorarensen et al. 1993), maximum metabolic rate (McKenzie et al. 2012) and swimming performance (Farrell et al. 1990, Pearson et al. 1990). There are also indications that exercise generates a more robust fish with a higher ability to cope with different challenges, such as pathogens (Castro et al. 2011).

Considering the positive effects of increased swimming speeds, exposed farming should be a favourable choice both in terms of production performance and fish welfare. There are, however, reports of water velocity at some fish farms that exceed the documented critical swimming speed of salmon (Øystein Patursson, Aquaculture Research Station at the Faroes, pers. comm.). Under these circumstances, fish welfare may be compromised. For instance, reduced growth (East \& Magnan 1987, Farrell et al. 1991) and decreased muscle energy stores (Jørgensen \& Jobling 1993) have been reported in fish forced to swim above optimal velocity. If energy reserves become depleted during intensive swimming, this could limit the fish's ability to cope with new challenges. In such instances, fast velocity may be perceived as a stressor that has a negative influence on fish performance and welfare.

In sea cages exposed to fast currents, fish are not able to choose their swimming speed. When the current increases, the fish must swim against it at the prevailing velocity to avoid being swept into the netting (Johansson et al. 2014).
Here we investigated the effects of slow, moderate and fast swimming speeds in Atlantic salmon postsmolts with regard to growth, muscle composition, blood chemistry and heart morphology. We used raceways to ensure that the fish swam at the same speed as the water current velocity. Our objective was to reveal whether there are any limitations or risks when locating new farms in areas exposed to fast water current velocity.

\section{MATERIALS AND METHODS}

\section{Facilities and experimental animals}

On 17 January 2012, 1000 Atlantic salmon parr (NLA strain, hatched March 2011) were transferred to 2 circular tanks $\left(\varnothing 3 \mathrm{~m}, 5.3 \mathrm{~m}^{3}\right)$ in the Tank Environmental Laboratory at the Institute of Marine Research, Matre (Norway). Fish were kept in freshwater at $8^{\circ} \mathrm{C}$ with a continuous flow of $1501 \mathrm{~min}^{-1}$ on a constant light regime for $8 \mathrm{wk}$ to complete smoltification. Prior to transfer, the fish had been reared in tanks $(\varnothing 5 \mathrm{~m})$ under natural light and temperature conditions. On 15 March, the water supply was changed to seawater (33 psu) and the temperature was slowly increased to $10^{\circ} \mathrm{C}$. Fish were kept under these conditions for $1 \mathrm{wk}$ prior to transfer into the experimental tanks. During the experiment, constant temperature $\left(10^{\circ} \mathrm{C}\right)$, water exchange $\left(120 \mathrm{l} \mathrm{min}^{-1}\right)$, salinity (33 psu) and a constant light regime were maintained. Dissolved oxygen levels were always above $80 \%$.

Twelve experimental raceways (Fig. 1) were designed to produce a homogeneous water current through an open cylinder. The trans-sectional area of the cylinder was $0.10 \mathrm{~m}^{2}(\varnothing 0.36 \mathrm{~m})$ and the length available for the fish was $2.0 \mathrm{~m}$, giving a volume of $0.20 \mathrm{~m}^{3}$. Raceways were fitted with an electric engine (Minn Kota RT80/EM, Johnson Outdoors Marine Electronics) with adjustable speed followed by a honeycomb $(5.0 \mathrm{~mm}$ opening and $101.6 \mathrm{~mm}$ long, PC 5.0 G4, Plascore) to generate a laminar flow. To keep the fish inside, a plastic-coated wire netting $(10 \times 10 \mathrm{~mm})$ was placed before a turbulence-reducing flow divider at the outlet and on the opening at the top (1.9 $\mathrm{m}$ long and $0.2 \mathrm{~m}$ wide). Each raceway was submerged in a circular tank $\left(\varnothing 3 \mathrm{~m}, 5.3 \mathrm{~m}^{3}\right)$ with the water surface just covering the cylinder of the raceway. Two cameras were mounted so that fish in both the front and back of the raceway could be observed. Fish $(98.6 \pm 20 \mathrm{~g}, 22.3 \pm 1.3 \mathrm{~cm}$, mean $\pm \mathrm{SD})$ were transferred to raceways on 22 March 2012, at a mean 

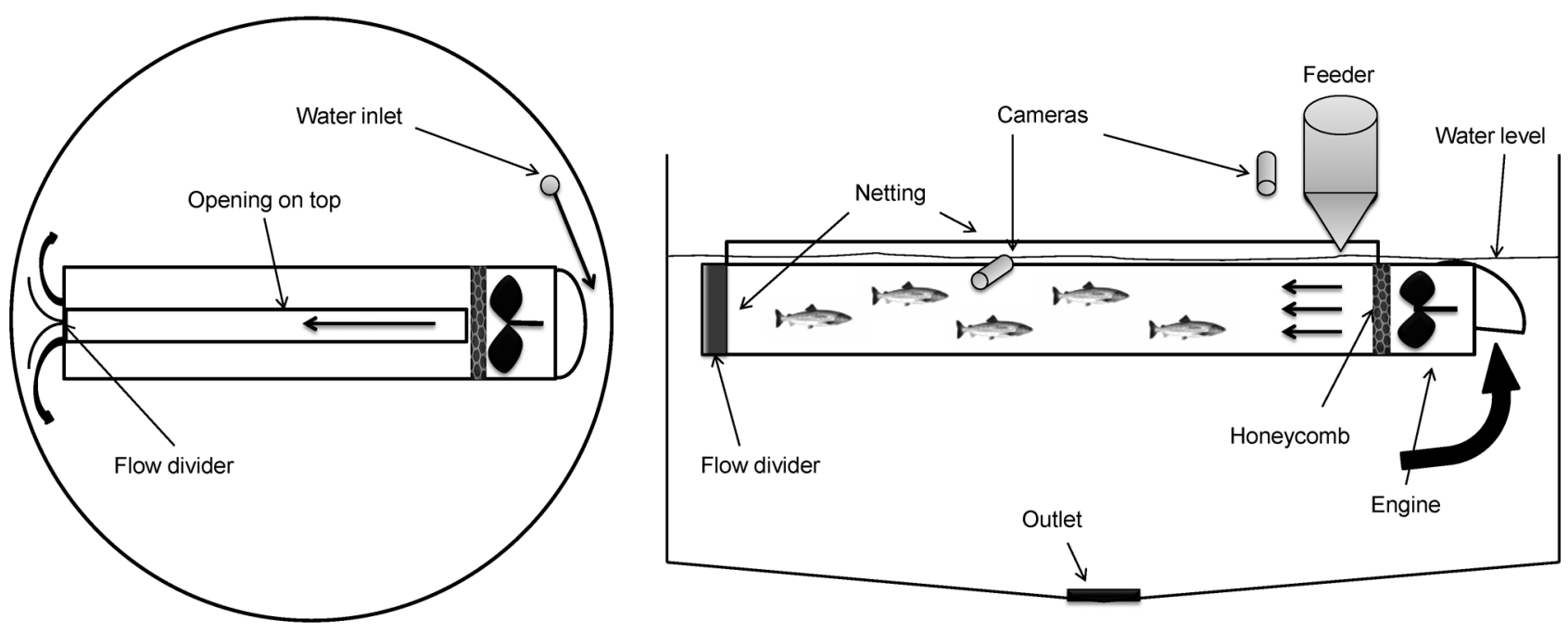

Fig. 1. Illustrative sketch of the constructed raceways submerged in tanks of $3 \mathrm{~m}$ diameter. The current in the raceway is driven by an electric engine through a honeycomb to create a homogeneous velocity. Thick arrows show the direction of water flow in the tank and raceway

$( \pm \mathrm{SE})$ stocking density of $38.7 \pm 0.28 \mathrm{~kg} \mathrm{~m}^{-3}$ ( $\mathrm{n}=80$ per raceway). Fish were acclimatized to the raceways for $19 \mathrm{~d}$ at a water current velocity of approximately $0.5 \mathrm{BL} \mathrm{s}^{-1}$.

\section{Experimental design}

On 10 April 2012, the water currents were adjusted in the raceways and the experiment started (Day 0). Three current regimes were generated in 4 replicate raceways: slow, moderate and fast velocities corresponding to $0.2 \pm 0.02,0.8 \pm 0.01$ and $1.5 \pm 0.02 \mathrm{BL} \mathrm{s}^{-1}$ (mean $\pm \mathrm{SE})$, respectively. The slow current velocity was chosen to be as close to $0.0 \mathrm{BL} \mathrm{s}^{-1}$ as possible, without compromising oxygen levels and the transport of faeces and food waste. The moderate current velocity was selected to be in the range of velocities previously described to have a positive effect in salmonids (East \& Magnan 1987, Houlihan \& Laurent 1987, Totland et al. 1987, Castro et al. 2011, Tudorache et al. 2011). The fast current velocity was chosen to be twice the amplitude of the moderate velocity but still below critical swimmig speed $\left(U_{\text {crit }}\right)$ (Tang \& Wardle 1992, Stevens et al. 1998). All tanks had the same water exchange, securing good water quality in all treatments and ensuring that velocity was the experimental factor. Prior to the experiment, profiles at 3 horizontal (front, middle and back) and 3 diagonally vertical (top, centre and bottom) points showed negligible variations in velocity. Increased turbulence was measured in close proximity to the honeycomb. However, daily observations showed that this area was avoided by the fish and hence we assumed that swimming speed would not be affected. During the experiment velocity was only measured at one point (middle, centre) to minimise disturbance for the fish.

Fish were held under these conditions for $6 \mathrm{wk}$. Halfway into the experiment the currents were adjusted to maintain the same body length per second as the fish grew.

Fish were fed (Skretting Spirit 75) at the front of the raceway. Food was provided in excess every $15 \mathrm{~min}$ throughout the day. Video recordings and stomach analysis during sampling demonstrated that fish were feeding at all velocities.

\section{Sampling procedures}

Prior to raceway transfer, all fish were anesthetised (100 $\mathrm{mg} \mathrm{l}^{-1}$ Finquel), weighed $( \pm 1 \mathrm{~g})$ and measured $( \pm 0.5 \mathrm{~cm})$. Condition factor was calculated according to the equation described below. Five fish from each tank were sampled at the beginning of Weeks 0 and 6. At the beginning of Weeks 2 and 4, 5 fish were removed from each tank to keep density down as the fish gained weight. The fish were rapidly netted and killed with a blow to the head. They were weighed and the total length was measured. Muscle samples were taken behind the dorsal fin and frozen in liquid nitrogen. Muscle samples for glycogen and energy phosphates were taken and frozen within $45 \mathrm{~s}$ of 
netting. Blood samples were taken from the caudal vein and distributed to heparinised Eppendorf tubes on ice within $5 \mathrm{~min}$. The heart (ventricle, atrium and bulbus arteriosus) was collected at the beginning of Week 6 and was fixed in $4 \%$ buffered formaldehyde prior to analysis.

After the final sampling, all remaining fish were anesthetised, weighed and measured.

\section{Analyses}

Blood. Blood samples for haematocrit were collected in capillary tubes and centrifuged for $2 \mathrm{~min}$ (StatSpin Multipurpose Centrifuge). Blood for haemoglobin analyses $(50 \mu \mathrm{l})$ was collected from the heparinised Eppendorf tubes and stored at $-80^{\circ} \mathrm{C}$. The remaining blood in the heparinised tubes was centrifuged at 3220 relative centrifugal force (RCF) at $4^{\circ} \mathrm{C}$ for $10 \mathrm{~min}$ and the resultant plasma was distributed into 2 Eppendorf tubes and stored at $-80^{\circ} \mathrm{C}$ prior to analyses.

Plasma samples were analysed for lactate and glucose using MaxMat PL (MaxMat). Osmolality was measured in $20 \mu \mathrm{l}$ plasma with Fiske 210 MicroSample Osmometer (Advanced Instruments) and ions were analyzed with Cobas c 111 System (Roche Diagnostics).

Haemoglobin samples were diluted 1:150 before analysis with a QuantiChrom Hemoglobin Assay Kit (DIHB-250) from BioAssay Systems.

Muscle. Muscle samples for analysis of protein, lactate, adenosine triphosphate (ATP), adenisone diphosphate (ADP), creatine phosphate $(\mathrm{CrP})$, creatine $(\mathrm{Cr})$, glucose, glycogen and lipids were freeze-dried for $48 \mathrm{~h}$. White muscle was dissected free from red muscle, skin and connective tissue and ground to a fine powder and stored at $-80^{\circ} \mathrm{C}$.

Protein analyses. Protein was extracted from $10 \mathrm{mg}$ of freeze-dried white muscle with $500 \mu \mathrm{l} 1 \mathrm{M} \mathrm{NaOH}$ in an ultrasonic bath for $10 \mathrm{~min}$. The samples were neutralised with $500 \mu \mathrm{l}$ radioimmunoprecipitation assay (RIPA) buffer and centrifuged (5400 RCF, 1 min and $4^{\circ} \mathrm{C}$ ), and the supernatant was diluted 1:10 in RIPA before being analysed using the Pierce BCA Protein Assay Kit (Pierce Biotechnology). Bovine serum albumin was used as protein standard.

Glucose and glycogen analyses. Glycogen was extracted from $10 \mathrm{mg}$ of freeze-dried material with $500 \mu \mathrm{l} 2.0 \mathrm{M} \mathrm{HCl}$ and hydrolysed at $90^{\circ} \mathrm{C}$ for $2 \mathrm{~h}$. After centrifugation (1810 RCF, 15 min and $4^{\circ} \mathrm{C}$ ), the supernatant was transferred to Eppendorf tubes and stored at $-80^{\circ} \mathrm{C}$ until further analysis. Free glucose was extracted from $20 \mathrm{mg}$ of freeze-dried white mus- cle with $200 \mu \mathrm{l} 2.0 \mathrm{M} \mathrm{HCl}$ before centrifugation (1810 $\mathrm{RCF}, 15 \mathrm{~min}$ and $4^{\circ} \mathrm{C}$ ). The supernatant (50 $\mu$ l) was stored at $-80^{\circ} \mathrm{C}$ until further analyses. After defrosting, samples were neutralised (1:1) with $2.0 \mathrm{M} \mathrm{NaOH}$ and diluted in buffer (9:1) (13.8 $\mathrm{g} \mathrm{NaH}_{2} \mathrm{PO}_{4}{ }^{*} \mathrm{H}_{2} \mathrm{O}$, $18.0 \mathrm{~g} \mathrm{Na}_{2} \mathrm{HPO}_{4}{ }^{*} 2 \mathrm{H}_{2} \mathrm{O}, 100 \mathrm{ml} \mathrm{H} \mathrm{H}_{2} \mathrm{O}$ ). Samples were analyzed using the Glucose Colorimetric Assay Kit (Cayman Chemical Company). Results were adjusted for dilution volume and the exact amount of tissue analysed. For glycogen results, the free glucose was subtracted from the results.

ATP and CrP analyses. Freeze-dried white muscle samples of $10 \mathrm{mg}$ were dissolved in $1000 \mu \mathrm{l} 0.4 \mathrm{M}$ perchloric acid by thoroughly mixing the samples and immersing them in an ultrasonic ice bath for $10 \mathrm{~min}$. After mixing, the samples were neutralised with $350 \mu \mathrm{l} 2.0 \mathrm{M} \mathrm{KOH}$, centrifuged (5400 RCF, $1 \mathrm{~min}$ and $4^{\circ} \mathrm{C}$ ) and purified by syringe filter (Acrodisc GHP, $0.45 \mu \mathrm{m}, 13 \mathrm{~mm}$ ). Analyses were performed immediately to prevent samples from decomposing. The injection volume was $20 \mu \mathrm{l}$. Results were adjusted for dilution volume and the amount of tissue analysed.

ATP, ADP, CrP and Cr were analysed using ultra high performance liquid chromatography (Nexera UHPLC, Shimadzu Corporation) with an adapted method based on Sellevold et al. (1986) and Volonté et al. (2004).

Isocratic chromatographic separation between substances was performed using a $\mathrm{C}_{18}$ HPLC column $(250 \times 4.6 \mathrm{~mm}, 5 \mu \mathrm{m}$ particle size, Supelco Discovery) at $30^{\circ} \mathrm{C}$. The flow of buffer $\left(215 \mathrm{mM} \mathrm{KH}{ }_{2} \mathrm{PO}_{4}, 3.5 \%\right.$ acetonitrile and $2.3 \mathrm{mM}$ TBAHS, $\mathrm{pH}$ 6.25) was set at $1.3 \mathrm{ml} \mathrm{min}{ }^{-1}$ and detection was performed at a wavelength of $215 \mathrm{~nm}$.

Stock solutions were prepared in $0.4 \mathrm{M}$ perchloric acid and diluted with buffer to standard concentrations: ATP $0.190 \mu \mathrm{mol} \mathrm{ml} l^{-1}$, ADP $0.0353 \mu \mathrm{mol} \mathrm{ml}^{-1}$, CrP $0.400 \mu \mathrm{mol} \mathrm{ml}{ }^{-1}$ and $\mathrm{Cr} 2.745 \mu \mathrm{mol} \mathrm{ml}{ }^{-1}$. The standard was injected in volumes of 10,20,30, 40 and $50 \mu \mathrm{l}$ to create a standard curve. After dilution with buffer, the solution was only stable for $30 \mathrm{~min}$.

Lipids. Lipids were extracted from approximately $100 \mathrm{mg}$ of freeze-dried white muscle according to Folch et al. (1957) and dried under a stream of nitrogen, and total lipids were measured gravimetrically.

\section{Heart morphology}

The atrium and the bulbus arteriosus were removed from all the fixed hearts and the remaining ventricle was weighed with $1 \times 10^{-4} \mathrm{~g}$ accuracy. The 
relative ventricular mass was calculated according to Eq. (2). Images of the caudal surface of the heart ventricle were used to determine the roundness of the ventricle according to Fraser et al. (2014).

\section{Calculations and statistics}

Condition factor. Fulton's condition factor (CF) was calculated according to the formula (Busacker et al. 1990):

$$
\mathrm{CF}=\frac{W}{L^{3}} \times 100
$$

where $W$ is the wet weight of the fish $(\mathrm{g})$, and $L$ is the length $(\mathrm{cm})$.

Relative ventricular mass. Relative ventricular mass (RVM) was calculated according to the formula (Gallaugher et al. 2001):

$$
\mathrm{RVM}=\frac{M_{\mathrm{v}}}{M_{\mathrm{b}}} \times 100
$$

where $M_{\mathrm{v}}$ is the ventricular mass and $M_{\mathrm{b}}$ is the total body mass of the fish $(\mathrm{g})$.

Statistical analysis. All results were checked for normality and homogeneity of variance. Percentage values were arcsin transformed prior to analyses. Outliers were individually investigated for underlying reasons and the outliers were removed from the data set where methodological causes were detected. Potential tank effects were equalised using nested ANOVA. Data that fulfilled the assumptions of normality and homogeneity were analysed with a 1-way ANOVA to test for significant differences $(p<0.05)$ between treatments. Data that did not meet the assumptions of homogeneity or normality were tested with the non-parametric Kruskal-Wallis test. All analyses were performed with Statistica (version 11, StatSoft). All presented values are shown as means \pm SE.

During the experiment, 2 replicates were eliminated due to technical problems - one from the fast current velocity in Week 5 and one from the moderate current velocity in Week 4 -resulting in triplicate treatments for the aforementioned groups at the final sampling.

\section{RESULTS}

\section{Growth}

At the start of the experiment there were no differences between treatments in weight, length or condi-
Table 1. Growth parameters (mean \pm SE) of post-smolt Atlantic salmon Salmo salar at the start and end of the experiment for the different water current velocity treatments (slow: $0.2 \pm 0.02$ body lengths [BL] s ${ }^{-1}$; moderate: $0.8 \pm$ $0.01 \mathrm{BL} \mathrm{s}^{-1}$; fast: $\left.1.5 \pm 0.02 \mathrm{BL} \mathrm{s}^{-1}\right)$. Significant differences $(p<0.05)$ are presented with superscripted letters

\begin{tabular}{|lccc|}
\hline & Slow & Moderate & Fast \\
\hline Weight (g) & & & \\
Start & $98 \pm 1$ & $100 \pm 1$ & $98 \pm 1$ \\
End & $250 \pm 3^{\mathrm{a}}$ & $251 \pm 3^{\mathrm{a}}$ & $238 \pm 3^{\mathrm{b}}$ \\
Length (cm) & & & \\
Start & $22.3 \pm 0.1$ & $22.3 \pm 0.1$ & $22.2 \pm 0.1$ \\
End & $28.4 \pm 0.1^{\mathrm{a}}$ & $28.4 \pm 0.1^{\mathrm{a}}$ & $27.9 \pm 0.1^{\mathrm{b}}$ \\
Condition factor & & \\
Start & $0.879 \pm 0.003$ & $0.885 \pm 0.003$ & $0.879 \pm 0.004$ \\
End & $1.079 \pm 0.004$ & $1.081 \pm 0.005$ & $1.086 \pm 0.006$ \\
\hline
\end{tabular}

tion factor (Table 1). After $6 \mathrm{wk}$, fish at all velocities had more than doubled their weight. Salmon at slow 'and moderate water current velocities were approximately $5 \%$ heavier and $2 \%$ longer compared to fish at fast velocity (Table 1). There was no difference in condition factor at the end of the experiment.

\section{Muscle composition}

Muscle composition differed among treatments at the end of the experiment (Table 2). Fish at the slow velocity had a higher lipid content compared to those kept at moderate and fast velocities. This was linked to lower protein content in dry matter (DM) and a 15 and $21 \%$ higher lipid content in this group of fish compared to fish in moderate and fast velocities, respectively (Table 2). Glycogen content was also $21 \%$ higher in fish kept at slow velocity compared to fast velocity, but not significantly higher compared to fish kept at moderate velocity. There were no effects of exercise on free glucose and ATP content in the muscle. However, CrP was 20 and $21 \%$ higher in fish kept at fast velocity compared to those kept at moderate and slow velocities, respectively.

\section{Blood chemistry}

At the end of the experiment there were some differences in the clinical blood parameters among the treatment groups (Table 3). There was a trend for reduced plasma osmolality related to exercise, with $1-2 \%$ lower values in the fast velocity group compared to the slow and moderate velocity groups. The 
Table 2. Muscle composition of post-smolt Atlantic salmon Salmo salar. Data are presented as mean \pm SE at the start and end of the experiment for the different velocity treatments (see Table 1). Significant differences $(p<0.05)$ are presented with superscripted letters. DM: dry matter; CrP: creatine phosphate

\begin{tabular}{|c|c|c|c|}
\hline & Slow & Moderate & Fast \\
\hline \multicolumn{4}{|c|}{ Protein $\left(\mathrm{g} \mathrm{g}^{-1} \mathrm{DM}\right)$} \\
\hline Start & $0.550 \pm 0.009$ & $0.544 \pm 0.007$ & $0.558 \pm 0.009$ \\
\hline End & $0.543 \pm 0.001^{\mathrm{b}}$ & $0.602 \pm 0.001^{\mathrm{a}}$ & $0.607 \pm 0.001^{\mathrm{a}}$ \\
\hline \multicolumn{4}{|c|}{ Lipids ( g $\left.^{-1} \mathrm{DM}\right)$} \\
\hline Start & $0.087 \pm 0.007$ & $0.082 \pm 0.005$ & $0.092 \pm 0.011$ \\
\hline End & $0.173 \pm 0.007^{\mathrm{a}}$ & $0.151 \pm 0.007^{b}$ & $0.143 \pm 0.008^{b}$ \\
\hline \multicolumn{4}{|c|}{ Glycogen ( $\mu \mathrm{mol} \mathrm{g}^{-1}$ protein) } \\
\hline Start & $117 \pm 9$ & $131 \pm 9$ & $126 \pm 7$ \\
\hline End & $156 \pm 8^{a}$ & $138 \pm 6^{\mathrm{a}, \mathrm{b}}$ & $129 \pm 4^{b}$ \\
\hline \multicolumn{4}{|c|}{ Glucose ( $\mu \mathrm{mol} \mathrm{g}^{-1}$ protein) } \\
\hline Start & $4.42 \pm 0.42$ & $4.26 \pm 0.33$ & $4.44 \pm 0.37$ \\
\hline End & $3.41 \pm 0.28$ & $2.61 \pm 0.21$ & $2.84 \pm 0.19$ \\
\hline \multicolumn{4}{|c|}{ ATP ( $\mu$ mol g ${ }^{-1}$ protein $)$} \\
\hline Start & $53.4 \pm 2.4$ & $55.0 \pm 1.6$ & $53.3 \pm 1.1$ \\
\hline End & $51.6 \pm 1.4$ & $48.6 \pm 1.0$ & $51.5 \pm 1.1$ \\
\hline \multicolumn{4}{|c|}{$\mathrm{CrP}\left(\mu \mathrm{mol} \mathrm{g}^{-1}\right.$ protein $)$} \\
\hline Start & $94 \pm 11$ & $108 \pm 13$ & $101 \pm 11$ \\
\hline End & $107 \pm 6^{b}$ & $108 \pm 5^{b}$ & $130 \pm 6^{\mathrm{a}}$ \\
\hline
\end{tabular}

reduction may be caused in part by general reductions in $\mathrm{K}^{+}$, but no effects on $\mathrm{Na}^{+}$and $\mathrm{Cl}^{-}$were detected, so there may be other factors affecting osmolality. An interesting result was the higher levels of $\mathrm{K}^{+}$and lactate in the slow velocity group compared to the other groups. No detectable treatment effects were found for haemoglobin, haematocrit or glucose.

\section{Heart morphology}

The relative ventricular mass of the fish kept at fast velocity was 15 and $10 \%$ higher than fish kept at moderate and slow velocities, respectively (Fig. 2). No effect on heart shape was observed (slow: $58 \pm$ $1.1^{\circ}$, moderate: $57 \pm 1.0^{\circ}$ and fast: $57 \pm 1.5^{\circ}$ ).

\section{DISCUSSION}

Our objective was to determine the effects of water current velocities on physiological and biochemical markers of fish welfare and production quality in post-smolt Atlantic salmon. A slow velocity led to alterations of many physiological characteristics, including indicators of stress and increased lipid deposition. A moderate velocity of $0.8 \mathrm{BL} \mathrm{s}^{-1}$ resulted in low values of stress-related parameters and best pro-
Table 3. Blood chemistry of post-smolt Atlantic salmon Salmo salar. Data are presented as mean \pm SE at the start and end of the experiment for the different velocity treatments (see Table 1). Significant differences $(p<0.05)$ are presented with superscripted letters

\begin{tabular}{|c|c|c|c|}
\hline & Slow & Moderate & Fast \\
\hline \multicolumn{4}{|c|}{ Haematocrit } \\
\hline Start & $32.9 \pm 0.8$ & $34.0 \pm 0.9$ & $30.7 \pm 1.0$ \\
\hline End & $38.1 \pm 1.0$ & $36.6 \pm 0.8$ & $37.9 \pm 1.1$ \\
\hline \multicolumn{4}{|c|}{ Haemoglobin $\left(\mathrm{g} \mathrm{dl}^{-1}\right)$} \\
\hline Start & $11.8 \pm 0.6$ & $11.7 \pm 0.6$ & $11.1 \pm 0.3$ \\
\hline End & $11.3 \pm 0.2$ & $10.9 \pm 0.2$ & $11.4 \pm 0.2$ \\
\hline \multicolumn{4}{|c|}{ Osmolality (mOsm kg kg $^{-1}$} \\
\hline Start & $341 \pm 3$ & $340 \pm 2$ & $343 \pm 2$ \\
\hline End & $351 \pm 2^{\mathrm{a}}$ & $348 \pm 1^{\mathrm{a}}$ & $343 \pm 2^{b}$ \\
\hline \multicolumn{4}{|c|}{$\mathrm{Na}^{+}\left(\mathrm{mmol} \mathrm{l}^{-1}\right)$} \\
\hline Start & $161 \pm 1$ & $161 \pm 1$ & $161 \pm 1$ \\
\hline End & $162 \pm 1$ & $162 \pm 1$ & $161 \pm 1$ \\
\hline \multicolumn{4}{|c|}{$\mathrm{K}^{+}\left(\mathbf{m m o l ~ l ^ { - 1 }}\right)$} \\
\hline Start & $0.530 \pm 0.039$ & $0.640 \pm 0.077$ & $0.512 \pm 0.032$ \\
\hline End & $0.841 \pm 0.134^{\mathrm{a}}$ & $0.486 \pm 0.031^{\mathrm{b}}$ & $0.430 \pm 0.016^{\mathrm{b}}$ \\
\hline \multicolumn{4}{|c|}{$\mathrm{Cl}^{-}\left(\mathrm{mmol} \mathrm{l} \mathbf{l}^{-1}\right)$} \\
\hline Start & $135 \pm 1$ & $135 \pm 1$ & $134 \pm 1$ \\
\hline End & $131 \pm 1$ & $131 \pm 1$ & $131 \pm 1$ \\
\hline \multicolumn{4}{|c|}{ Lactate $\left(\mathrm{mmol} \mathrm{l}^{-1}\right)$} \\
\hline Start & $0.750 \pm 0.071$ & $0.740 \pm 0.045$ & $0.805 \pm 0.073$ \\
\hline End & $0.860 \pm 0.16^{\mathrm{a}}$ & $0.500 \pm 0.041^{\mathrm{b}}$ & $0.380 \pm 0.033^{b}$ \\
\hline \multicolumn{4}{|c|}{ Glucose $\left(\mathrm{mmol} \mathrm{l}^{-1}\right)$} \\
\hline Start & $6.33 \pm 0.15$ & $6.09 \pm 0.15$ & $6.06 \pm 0.17$ \\
\hline End & $6.51 \pm 0.15$ & $6.33 \pm 0.10$ & $6.37 \pm 0.15$ \\
\hline
\end{tabular}

duction results, and hence a higher welfare compared to the other groups. At fast velocity $\left(1.5 \mathrm{BL} \mathrm{s}^{-1}\right)$, growth was reduced, while at slow velocity $(0.2 \mathrm{BL}$ $\mathrm{s}^{-1}$ ), some physiological parameters such as lactate had a large individual variation, possibly as an effect of agonistic behaviour.

\section{Growth}

Fish swimming at fast water current velocity had a lower growth compared to fish swimming at slow and moderate velocities. Previous studies have shown improved growth when fish have been forced to swim against a current (East \& Magnan 1987, Houlihan \& Laurent 1987, Totland et al. 1987, Christiansen \& Jobling 1990, Jørgensen \& Jobling 1993, Davison 1997, Castro et al. 2011).

A significant challenge when determining the effects of prolonged swimming at different speeds in fish is the generation of a homogeneous water current within the test environment. In many earlier experiments, the homogeneity of the water current was difficult to evaluate, making interpretation of the 


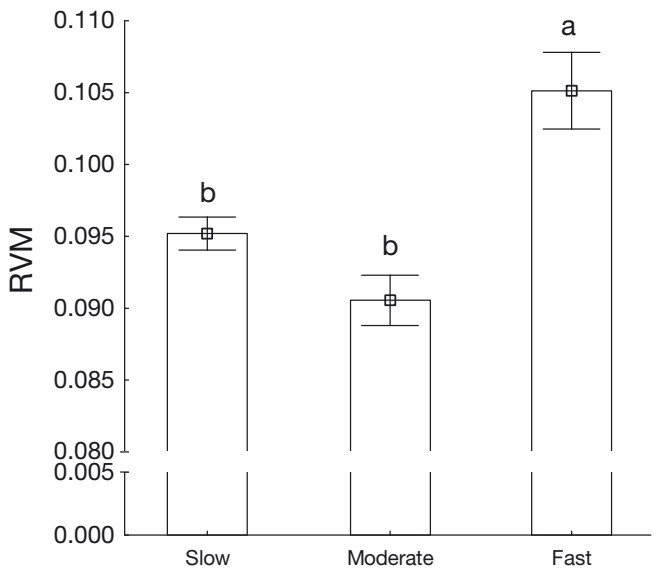

Fig. 2. Relative ventricular mass (RVM, mean $\pm \mathrm{SE}$ ) in Atlantic salmon Salmo salar in slow, moderate and fast velocity groups (see Table 1) at the end of the experiment. Significant differences between groups $(p<0.05)$ are presented with lowercase letters

data difficult. The use of circular tanks without any constraints is a good example of an experiment in which a homogeneous current velocity is difficult to achieve. For instance, within circular tanks the water velocity may be over 3 times faster closer to the outside wall (Duarte et al. 2011) and the fish can change position and thereby vary the experienced current velocity. In addition, if the fish is not restricted to a closed off section in the tank (hereafter referred to as closed/open circular if a closed off section exists/is absent) this may also influence the results as the fish have the ability to move either slower or faster than the generated current and the actual swimming speed of individual fish will be unknown. This seems to be the case in several studies (East \& Magnan 1987, Christiansen \& Jobling 1990, Jørgensen \& Jobling 1993, Kiessling et al. 1994, Adams et al. 1995, Gallaugher et al. 2001, Larsen et al. 2012, McKenzie et al. 2012). The difficulties in evaluating current homogeneity and actual swimming speed may explain inconsistencies in results within the literature. However, relative differences of exercised and unexercised fish may still be observable. Constraining the fish may also be stressful if they do not have the possibility to change position or vary swimming speed. In the present study, the available length of space for the fish was 9 to 7 body lengths as the fish grew, allowing the fish to change position.

Castro et al. (2011) observed an increase in growth for pre-smolt Atlantic salmon kept at both continuous and alternating current velocities compared to control fish kept at minimal current velocity. Their continuous current velocity corresponded to our moder- ate velocity, but the study was conducted in a closed area in circular tanks where velocity may differ between the inner and outer tank walls. Jørgensen \& Jobling (1993) observed an optimal growth at a water current velocity of 1.5 $\mathrm{BL} \mathrm{s}^{-1}$ in juvenile salmon, corresponding to our fast velocity, which resulted in suboptimal growth in our study. However, their study was carried out in open circular tanks where fish were free to move around and where actual swimming speeds might have differed from the water current velocity. Furthermore, in several studies (East \& Magnan 1987, Christiansen \& Jobling 1990, Jørgensen \& Jobling 1993, Castro et al. 2011), the slow velocities were close to zero and fish then would likely have had the possibility to move around and interact freely. This could also account for the inconsistencies in results within the literature where fish at slow velocity may display more agonistic behaviour than at higher velocities. Agonistic behaviour has been linked to a higher energy demand than swimming in Arctic charr (Adams et al. 1995), resulting in decreased growth at slow velocity.

To our knowledge, no previous studies of postsmolt Atlantic salmon have found clear negative effects on growth from exercise. Jørgensen \& Jobling (1993) observed a smaller increase in growth in juvenile fish kept at the fastest velocity $\left(2.0 \mathrm{BL} \mathrm{s}^{-1}\right)$ but only compared to fish kept at 1.0 and $1.5 \mathrm{BL} \mathrm{s}^{-1}$, whereas we observed negative effects already at 1.5 $\mathrm{BL} \mathrm{s}^{-1}$. However, as discussed above, the discrepancies may be due to different experimental setups or may be an effect of testing different life stages. In a study on adult rainbow trout using a setup for fast velocity more similar to ours, Farrell et al. (1991) observed decreased growth at swimming speeds of 1.0-1.4 BL s ${ }^{-1}$ compared to fish kept at minimal velocity, which corresponds better with our results. The reduced growth was due to a reduction in feeding for fish at the faster velocity, resulting in less energy for growth. Our setup did not allow control of feed intake, but the stomach contents and visual observations indicated that all fish fed. All fish had also doubled their weight during the experiment, indicating good food accessibility. Kiessling et al. (1994) also observed a higher energy demand for exercised Chinook salmon expressed as an increase in feed intake. But their study was conducted in open circular systems where absolute swimming speed is difficult to evaluate. However, an increase in energy demand may explain the reduced growth at fast velocity in our study, where fish must allocate a large part of their available energy into swimming with less energy left for growth. 


\section{Metabolic effects and blood chemistry}

We found that at moderate velocity, fish growth was more related to an increase in muscle mass in comparison to slow velocity, where part of the growth was due to increased lipid deposition. Increased lipid content with increased growth at faster velocity has been observed by East \& Magnan (1987) in open circular systems. However, both Farrell et al. (1991) and Lauff \& Wood (1996) found increased lipid metabolism in aerobically exercised rainbow trout, which could explain our findings with decreased lipid content and increased protein content in fish at moderate and fast velocities. Higher protein content associated with increased swimming speeds has also been observed by Houlihan \& Laurent (1987), with white muscle protein synthesis positively correlated to whole animal growth rates. In the present study, intramuscular glycogen and lipids were higher in the fish kept at slow velocity, indicating an accumulation of intramuscular energy. ATP content did not differ between velocities. Depletion of ATP is closely linked to fatigue (McFarlane \& McDonald 2002, Richards et al. 2002), which indicates that, irrespective of current velocity, the fish in the present study did not deplete their energy reserves, nor were they close to fatigue. In addition, lactate levels were not elevated in the fast velocity treatment, which may have been expected if there was anaerobic swimming activity. There was however, an increase in $\mathrm{CrP}$ in fish kept at fast velocity. This may be explained by an upregulation of the $\mathrm{CrP}$ shuttle, compensating for an increased demand for ATP transport from the mitochondria, as observed in humans (Perry et al. 2012).

In our setup, fish at all velocities were forced to swim at the given velocity as there were limited possibilities to swim faster, slower or stand on the bottom. However, at slow velocity, the fish interacted and displayed more agonistic behaviours compared to fish at moderate and fast velocities (F. Solstorm et al. unpubl.). This likely explains the higher levels of and greater variation in lactate and potassium at slow velocity in comparison to the moderate and fast velocities, since fish displaying dominant behaviour may stress subordinate fish. Yet, this behavioural effect did not result in decreased growth, as previously described by Adams et al. (1995), suggesting that our setup minimised the effects of behaviour on growth. Osmolality could also be affected by behavioural stress, but our lower values in the fast velocity group are more likely caused by a physiological adaptation to the high swimming activity, as described by Gallaugher et al. (2001).
The lack of detectable treatment effects on haematocrit and haemoglobin levels may be affected by sampling time, as Djordjevic et al. (2012) discerned that values over 30 in haematocrit likely reflect sampling stress. However, they used cannulated fish, a method that reduces sampling stress, but unfortunately that was not possible in our setup.

\section{Heart morphology}

Relative heart size was greater in the fastest velocity group compared to the slow and moderate velocity groups. This result is in line with previous studies on exercised salmonids (Gallaugher et al. 2001, Castro et al. 2013), even considering differences in setup, although exceptions do exist (Farrell et al. 1990). The increase in heart size is most likely related to an increased cardiac workload during sustained swimming through an increase in aerobic respiration. For instance, improvements in cardiac output and output power (Farrell et al. 1991), increased active metabolic rate (Gallaugher et al. 2001), and increased number of capillaries (Davie et al. 1986) are known to result from exercise training in salmon.

\section{CONCLUSIONS}

Fish kept at a water velocity of $1.5 \mathrm{BL} \mathrm{s}^{-1}$ had a lower production performance than fish kept at either 0.8 or $0.2 \mathrm{BL} \mathrm{s}^{-1}$. The slow velocity resulted in fish with higher lipid and lower protein content in the muscle compared to fish kept at moderate and fast velocities. Hence, fish kept at moderate velocity grew well and had a high protein content, indicating an efficient energy conversion. The reduction in growth in fish kept at fast velocity should be taken into account when evaluating new fish farm sites with fast water current velocity if the goal is to maximise production performance manifested as increase in total biomass. Based on our study and setup, it may be argued that water velocity over $1.5 \mathrm{BL} \mathrm{s}^{-1}$ could become problematic for Atlantic salmon. However, the results are evaluated on the strain, fish size and density that we employed at a temperature of $10^{\circ} \mathrm{C}$. The slow velocity in this study is more difficult to relate to commercial farms since the fish in farms normally swim at higher speeds than the water velocity, whereas in the present study they had to swim at given velocity because of space restrictions. To benefit from the positive effects of exposed farming, such as better water quality and fewer conflicting 
interests, the fish's swimming limitations need to be taken into account. Cages may need to be modified to create a more optimal environment with regard to currents. Furthermore, it may be worthwhile to study whether salmon from different strains and degrees of domestication perform better in fast velocity and may thereby be more suitable for production in exposed areas.

Acknowledgements. The authors thank the staff at IMR Matre for all their help and contributions. Special thanks are extended to laboratory technicians Karen Anita Kvestad and Grethe Thorsheim. We thank John Fleng Steffensen for his expert advice and help. We owe our gratitude to Tim Dempster for contributing his expertise. This study was supported by the Research Council of Norway grant no. 207116/S40.

\section{LITERATURE CITED}

Adams CE, Huntingford FA, Krpal J, Jobling M, Burnett SJ (1995) Exercise, agonistic behavior and food acqusition in Arctic charr, Salvelinus alpinus. Environ Biol Fishes 43:213-218

> Andrew JE, Noble C, Kadri S, Jewell H, Huntingford FA (2002) The effect of demand feeding on swimming speed and feeding responses in Atlantic salmon Salmo salar L., gilthead sea bream Sparus aurata L. and European sea bass Dicentrarchus labrax L. in sea cages. Aquacult Res 33:501-507

Benetti DD, Benetti GI, Rivera JA, Sardenberg B, O'Hanlon B (2010) Site selection criteria for open ocean aquaculture. Mar Technol Soc J 44:22-35

Blyth PJ, Purser GJ, Russel JF (1993) Detection of feeding rhythms in seacaged Atlantic salmon using a new feeder technology. In: Reinertsen H, Dahle LA, Jørgensen L, Tvinnereim K (eds) Fish farming technology. Balkema, Rotterdam, p 209-216

Busacker GP, Adelman IR, Goolish EM (1990) Growth. In: Schreck CB, Moyle PB (eds) Methods for fish biology. American Fisheries Society, Bethesda, MD, p 363-387

- Castro V, Grisdale-Helland B, Helland SJ, Kristensen T, and others (2011) Aerobic training stimulates growth and promotes disease resistance in Atlantic salmon (Salmo salar). Comp Biochem Physiol A 160:278-290

Castro V, Grisdale-Helland B, Helland SJ, Torgersen J, and others (2013) Cardiac molecular-acclimation mechanisms in response to swimming-induced exercise in Atlantic salmon. PLoS ONE 8:e55056

> Christiansen JS, Jobling M (1990) The behavior and the relationship between food-intake and growth of juvenile Arctic charr, Salvelinus alpinus L, subjected to sustained exercise. Can J Zool 68:2185-2191

> Davie PS, Wells RMG, Tetens V (1986) Effects of sustained swimming on rainbow trout muscle structure, blood oxygen transport, and lactate dehydrogenase isozymes: evidence for increased aerobic capacity of white muscle. J Exp Zool 237:159-171

> Davison W (1997) The effects of exercise training on teleost fish, a review of recent literature. Comp Biochem Physiol A 117:67-75

> Dempster T, Juell JE, Fosseidengen JE, Fredheim A, Lader P
(2008) Behaviour and growth of Atlantic salmon (Salmo salar L.) subjected to short-term submergence in commercial scale sea-cages. Aquaculture 276:103-111

Djordjevic B, Kristensen T, Overli O, Rosseland BO, Kiessling A (2012) Effect of nutritional status and sampling intensity on recovery after dorsal aorta cannulation in free-swimming Atlantic salmon (Salmo salar L.). Fish Physiol Biochem 38:259-272

> Duarte S, Reig L, Masalo I, Blanco M, Oca J (2011) Influence of tank geometry and flow pattern in fish distribution. Aquacult Eng 44:48-54

- East P, Magnan P (1987) The effect of locomotor activity on the growth of brook charr, Salvelinus fontinalis Mitchill. Can J Zool 65:843-846

> Farrell AP, Johansen JA, Steffensen JF, Moyes CD, West TG, Suarez RK (1990) Effects of exercise training and coronary ablation on swimming performance, heart size, and cardiac enzymes in rainbow trout, Oncorhynchus mykiss. Can J Zool 68:1174-1179

> Farrell AP, Johansen JA, Suarez RK (1991) Effects of exercise training on cardiac performance and muscle enzymes in rainbow trout, Oncorhynchus mykiss. Fish Physiol Biochem 9:303-312

Folch J, Lees M, Stanley GHS (1957) A simple method for the isolation and purification of total lipides from animal tissues. J Biol Chem 226:497-509

> Fraser TWK, Fleming MS, Poppe TT, Hansen T, Fjelldal PG (2014) The effect of ploidy and incubation temperature on survival and the prevalence of aplasia of the septum transversum in Atlantic salmon, Salmo salar L. J Fish Dis 37:189-200

Fredheim A, Langan R (2009) Advances in technolohy for off-shore and open ocean finfish aquaculture. In: Burnell G, Allan G (eds) New technologies in aquaculture: improving production efficiency, quality and environmental management. Woodhead Publishing in Food Science, Technology and Nutrition, Cambridge, p 914-944

Gallaugher PE, Thorarensen H, Kiessling A, Farrell AP (2001) Effects of high intensity exercise training on cardiovascular function, oxygen uptake, internal oxygen transport and osmotic balance in chinook salmon (OnCorhynchus tshawytscha) during critical speed swimming. J Exp Biol 204:2861-2872

Holmer M (2010) Environmental issues of fish farming in offshore waters: perspectives, concerns and research needs. Aquacult Environ Interact 1:57-70

Houlihan DF, Laurent P (1987) Effects of exercise training on the performance, growth, and protein turnover of rainbow trout (Salmo gairdneri). Can J Fish Aquat Sci 44: 1614-1621

> Johansson D, Laursen F, Ferno A, Fosseidengen JE, and others (2014) The interaction between water currents and salmon swimming behaviour in sea cages. PLoS ONE 9:e97635

> Jørgensen EH, Jobling M (1993) The effects of exercise on growth, food utilization and osmoregulatory capacity of juvenile Atlantic salmon, Salmo salar. Aquaculture 116: 233-246

Kadri S, Metcalfe NB, Huntingford FA, Thorpe JE (1991) Daily feeding rhythms in Atlantic salmon in sea cages. Aquaculture 92:219-224

Kiessling A, Higgs DA, Dosanjh BS, Eales JG (1994) Influence of sustained exercise at two ration levels on growth and thyroid function of all-female chinook salmon (Oncorhynchus tshawytscha) in seawater. Can J Fish Aquat 
Sci 51:1975-1984

Korsoen OJ, Dempster T, Fjelldal PG, Oppedal F, Kristiansen TS (2009) Long-term culture of Atlantic salmon (Salmo salar L.) in submerged cages during winter affects behaviour, growth and condition. Aquaculture 296: 373-381

> Larsen BK, Skov PV, McKenzie DJ, Jokumsen A (2012) The effects of stocking density and low level sustained exercise on the energetic efficiency of rainbow trout (OnCorhynchus mykiss) reared at $19^{\circ} \mathrm{C}$. Aquaculture $324-325$ : 226-233

Lauff RF, Wood CH (1996) Respiratory gas exchange, nitrogenous waste excretion, and fuel usage during aerobic swimming in juvenile rainbow trout. J Comp Physiol B 166:501-509

McFarlane WJ, McDonald DG (2002) Relating intramuscular fuel use to endurance in juvenile rainbow trout. Physiol Biochem Zool 75:250-259

McKenzie DJ, Hoglund E, Dupont-Prinet A, Larsen BK, Skov PV, Pedersen PB, Jokumsen A (2012) Effects of stocking density and sustained aerobic exercise on growth, energetics and welfare of rainbow trout. Aquaculture 338-341:216-222

Pearson MP, Spriet LL, Stevens ED (1990) Effect of sprint training on swim performance and white muscle metabolism during exercise and recovery in rainbow trout (Salmo gairdneri). J Exp Biol 149:45-60

> Perry CGR, Kane DA, Herbst EAF, Mukai K, and others (2012) Mitochondrial creatine kinase activity and phosphate shuttling are acutely regulated by exercise in human skeletal muscle. J Physiol 590:5475-5486

Richards JG, Heigenhauser GJF, Wood CM (2002) Glycogen phosphorylase and pyruvate dehydrogenase transformation in white muscle of trout during high-intensity exercise. Am J Physiol Regul Integr Comp Physiol 282:

Editorial responsibility: Chris Noble, Tromsø, Norway
R828-R836

> Sellevold OFM, Jynge P, Aarstad K (1986) High performance liquid chromatography: a rapid isocratic method for determination of creatine compounds and adenine nucleotides in myocardial tissue. J Mol Cell Cardiol 18: $517-527$

Stevens ED, Sutterlin A, Cook T (1998) Respiratory metabolism and swimming performance in growth hormone transgenic Atlantic salmon. Can J Fish Aquat Sci 55: 2028-2035

Stickney RR, McVey JP (2002) Responsible marine aquaculture. CABI Publishing, Wallingford

Sutterlin AM, Jokola KJ, Holte B (1979) Swimming behaviour of salmonid fish in ocean pens. J Fish Res Board Can 36:948-954

Tang J, Wardle CS (1992) Power output of two sizes of Atlantic salmon (Salmo salar) at their maximum sustained swimming speeds. J Exp Biol 166:33-46

Thorarensen H, Gallaugher PE, Kiessling AK, Farrell AP (1993) Intestinal blood flow in swimming chinook salmon Oncorhynchus tshawytscha and the effects of hematocrit on blood flow distribution. J Exp Biol 179:115-129

- Totland GK, Kryvi H, Jodestol KA, Christiansen EN, Tangeras A, Slinde E (1987) Growth and composition of the swimming muscle of adult Atlantic salmon (Salmo salar L.) during long-term sustained swimming. Aquaculture 66: 299-313

Tudorache C, O'Keefe RA, Benfey TJ (2011) Optimal swimming speeds reflect preferred swimming speeds of brook charr (Salvelinus fontinalis Mitchill, 1874). Fish Physiol Biochem 37:307-315

> Volonté MG, Yuln G, Quiroga P, Consolini AE (2004) Development of an HPLC method for determination of metabolic compounds in myocardial tissue. J Pharmaceut Biomed Anal 35:647-653

Submitted: September 15, 2014; Accepted: July 23, 2015 Proofs received from author(s): September 3, 2015 